University of Nebraska - Lincoln

DigitalCommons@University of Nebraska - Lincoln

Faculty Publications, Department of Psychology

Psychology, Department of

December 1996

\title{
Use of folk healing practices by HIV-infected Hispanics living in the United States
}

\author{
Mariana Suarez \\ Rutgers University \\ Marcela Raffaelli \\ University of Nebraska-Lincoln, mraffaelli1@unl.edu \\ Ann O'Leary \\ Rutgers University
}

Follow this and additional works at: https://digitalcommons.unl.edu/psychfacpub

Part of the Psychiatry and Psychology Commons

Suarez, Mariana; Raffaelli, Marcela; and O'Leary, Ann, "Use of folk healing practices by HIV-infected Hispanics living in the United States" (1996). Faculty Publications, Department of Psychology. 224. https://digitalcommons.unl.edu/psychfacpub/224

This Article is brought to you for free and open access by the Psychology, Department of at DigitalCommons@University of Nebraska - Lincoln. It has been accepted for inclusion in Faculty Publications, Department of Psychology by an authorized administrator of DigitalCommons@University of Nebraska - Lincoln. 


\title{
Use of folk healing practices by HIV-infected Hispanics living in the United States
}

\author{
Mariana Suarez, ${ }^{1}$ Marcela Raffaelli, ${ }^{2}$ and Ann O'Leary ${ }^{1}$ \\ ${ }^{1}$ Department of Psychology, Rutgers University, New Brunswick, New Jersey \\ ${ }^{2}$ University of Nebraska, Department of Psychology, Lincoln, Nebraska, USA
}

\begin{abstract}
In the absence of a medical cure for AIDS, HIV-infected individuals may seek alternative treatments that are consistent with cultural and social beliefs. This paper examines beliefs about, and use of, folk healing practices by HIV-infected Hispanics receiving care at an HIV/AIDS clinic in inner-city New Jersey. Anonymous individual interviews were conducted with 58 male and 18 female HIV-infected Hispanics aged 23-55, primarily of Puerto Rican origin (61\%) or descent (29\%). The majority of respondents believed in good and evil spirits (73.7\%); among the 56 believers, $48 \%$ stated that the spirits had a causal role in their infection, either alone or in conjunction with the AIDS virus. Two thirds of the respondents engaged in folk healing (spiritualism and/or santeria). The main desired outcomes of folk healing included physical relief $(44 \%)$, spiritual relief $(40 \%)$, and protection from evil $(26 \%)$. A number of respondents $(n=9)$ stated that they hoped to effect a cure by engaging in folk healing. These results indicate that health care professionals treating HIV-positive Hispanics should be aware of the prevalence of folk beliefs and alternative healing practices in this population.
\end{abstract}

\section{Introduction}

Folk medical beliefs and practices have been identified as potentially important aspects of patient experience. Despite recognition that such phenomena are prevalent and may affect use of biomedical services (Pachter, 1994) folk beliefs and practices regarding HIV/AIDS have been virtually unexplored. On the other hand, it is known that some HIV-infected individuals seek treatments that may be considered 'alternative', such as massage and nutritional supplementation. In the absence of a medical cure for AIDS, it is natural that those affected may use non-medical treatments to manage and alleviate symptoms of the disease.

Hispanics living in the US are a group disproportionately affected by HIV infection and AIDS. Although Hispanics represent only $10 \%$ of the total US population (US Bureau of the Census, 1995), they account for $17 \%$ of all AIDS cases. As of June 1995 81,344 cases of AIDS had been reported among Hispanics (Centers for Disease Control and Prevention, 1995). Among Hispanics, those of Puerto Rican descent and living in the north-east US are especially affected (Selik et al., 1989). Puerto Ricans are known to employ folk medical practices. Ethnographic, clinical and population-based survey data reveal that anywhere from $18-80 \%$ of native Puerto Ricans have visited a spiritualist practitioner at some time in their lives (Garrison, 1977; Hohmann et al., 1990; Koss, 1987; Rogler \& Hollingshead, 1965) and similar findings have been found for Puerto Ricans living in New York (Garrison, 1977; Hohmann et al., 1990; Koss, 1987; Lubchansky et 
al., 1970; Rogler \& Hollingshead, 1965). Thus, it would appear likely that HIV-infected Hispanics may turn to folk healing practices to manage their illness. However, to date, virtually no research has been conducted to examine this issue.

This study focused on the two primary types of folk healing practised by Puerto Ricans living in the North-eastern part of the US: espiritismo and santeria. Espiritismo incorporates elements of Spanish, European, African and Indian folk practices (Hohmann et al., 1990; Ness \& Wintrob, 1981). The central premise of espiritismo is that both the material and immaterial world are inhabited by good and evil spirits who have the power to influence the thoughts and behaviours of human beings (Ness \& Wintrob, 1981; Rogler \& Hollingshead, 1965; Weiss, 1992). Santeria as practised by Puerto Ricans living in the US represents an adaptation of traditional santeria, which has its roots in African religion and Catholicism (Weiss, 1992). The cornerstone of santeria is worship of the saints in exchange for supernatural powers and protection (GonzalezWhippler, 1982). Because of the overlap between espiritismo and santeria as practised by Puerto Ricans, for the purposes of this exploratory study we did not distinguish between these two spiritualist belief systems. These folk practices are not considered by their practitioners to be incompatible with biomedical treatments, and are often carried out concurrently (Garner \& Duckett, 1992; Koss, 1987; Pachter, 1994).

The goals of this study were to explore:

(1) extent of involvement in folk healing practices by HIV-infected Hispanics;

(2) types of practices engaged in;

(3) beliefs regarding outcomes of folk practices;

(4) predictors of involvement in folk healing practices.

\section{METHODS}

\section{Procedures}

Data were collected during 2 weeks in 1989 and 1 month in 1991. During these times, all Hispanics in the waiting room of a hospital-based HIV/AIDS treatment clinic serving indigent populations in northern New Jersey were approached and invited to participate in the study. Only two individuals declined to be interviewed. After completing informed consent procedures individual interviews were conducted by the first author in English or Spanish, depending on the preference of the participant. Respondents remained anonymous and were paid $\$ 5.00$ for participating.

\section{Sample}

The sample consisted of 76 respondents (58 male, 18 female) between the ages of 23 and 55 (37\% were less than 30 years old, $50 \%$ between 31 and 40 , and $13 \%$ over 40 years old). The majority of respondents had been born in Puerto Rico (61\%) or were of Puerto Rican ancestry (29\%); the remainder were from other Caribbean or Latin American countries (10\%). Fifty respondents chose to be interviewed in English (65.8\%) and 26 in Spanish (34.2\%). Over half $(55 \%)$ had not completed high school, $25 \%$ were high school graduates, and $20 \%$ had some higher education.

All respondents were receiving medical care for their HIV infection; over two-thirds (69.7\%) were HIV-positive but asymptomatic and the remaining respondents (30.3\%) had AIDS-related symptoms (7.9\% were diagnosed as having 'AIDS-related complex' and $22.4 \%$ had full-blown AIDS). Reported transmission routes for HIV infection were injected drug use (55.3\%), malemale intercourse (17.1\%), male-female intercourse (19.7\%), or multiple risk factors $(7.9 \%)$. 


\section{Measures}

The semi-structured interview protocol was developed by conducting informal interviews with key informants and a review of the literature. Topics included basic demographics, life circumstances, assessments of involvement in folk healing (espiritismo and/or santeria), traditional religious, and other alternative practices (e.g. meditation, massage, visualization) and sexual behaviour. In addition, depression was assessed with the CES-D (Radloff, 1977). Because the factor structure of the CES-D has been found to differ among Hispanic subgroups (Guarnaccia et al., 1989), overall scores were used in the analyses of depression levels.

\section{RESULTS}

Participants were asked whether they believed in good and evil spirits; the majority said they did $(73.7 \% ; n=56)$. When asked what had caused their illness, many of the 56 believers stated that spirits played a causal role in their infection, either alone (9\%) or in conjunction with the AIDS virus (39\%); only a third (32\%) attributed the disease to the AIDS virus only, and one-fifth did not know what had caused their illness.

\section{Extent of involvement in folk practices}

All respondents were asked whether they engaged in folk, religious, and other alternative healing practices. Over three-quarters reported doing so, with the majority engaging in folk healing, either alone or in combination with traditional religious and other alternative practices (Table 1).

\section{Types of practices}

The types of practices engaged in by practitioners of folk healing are displayed in Table 2. Many of these practices resemble traditional religious practices, but are engaged in outside church settings and reflect spiritualist belief systems.

The most commonly reported practices included saying spiritualist prayers, making a promise and lighting candles. Many believers reported using healing items such as holy water (blessed by a spiritualist), candles, oils, incense and special baths, herbs and prayer books containing spiritualist prayers. These items may be purchased at botanicas (stores where folk paraphernalia are

Table 1. Proportion of respondents who engaged in folk healing, religious, or other alternative practices $(n=76)$

\begin{tabular}{lrc}
\hline & $\mathbf{n}$ & \% \\
\hline No & 17 & 22.4 \\
Religious/other alternative only & 9 & 11.8 \\
Folk healing & 50 & 65.8 \\
Folk healing only & $(14)$ & $(18.4)$ \\
Folk healing and religion & $(12)$ & $(15.8)$ \\
Folk healing and other alternative & $(6)$ & $(7.9)$ \\
All three & $(18)$ & $(23.7)$ \\
\hline
\end{tabular}


sold) and are used either at home or in a more formal setting such as a Centro Espiritista (spiritualist centre). These Centros may be located in a private home, storefront, or a rented hall. They are headed by a spiritualist who holds services, conducts special masses, and offers private consultations. The spiritualist may also bless special necklaces which are worn for protection, and recommend further courses of action that the individual can follow. In addition, individuals may engage in self-treatment, without going to a healer.

\section{Beliefs regarding outcomes of folk practices}

Respondents were asked what they hoped to achieve by engaging in each folk healing practice they described performing. Open-ended responses were coded into inductively-derived content categories; the distribution of responses is summarized in Table 3. It should be noted that the same spiritualist practices can be used to achieve different outcomes, depending on the intent of the believer. The individual, either alone or in consultation with an adviser, determines the course of action to follow for a desired result. For example, one respondent described maintaining frequent contact with his santero (spiritualist practitioner), who would recommend ways of achieving relief and protection. The santero recommended that he light candles, take baths with special herbs, and wear a special necklace to protect him from witchcraft. The santero also "worked" on his pants and suits so that "evil would leave"; the respondent said he hoped that this would lead to a cure.

The most common reason for practising folk healing was to attain physical relief; over twofifths of believers said that they were seeking physical relief of some kind. The 22 respondents sought the following types of physical relief (some gave more than one answer): general relief (n

Table 2. Proportion of respondents engaging in specific folk healing practices (among those reporting any involvement; $\mathrm{n}=50$ )

\begin{tabular}{ll}
\hline Type of practice & $\%$ \\
\hline Pray & 52.0 \\
Make a promise & 40.0 \\
Light candles & 38.0 \\
Holy water & 34.0 \\
Glasses of water & 32.0 \\
Offerings/feast for patron saint & 29.0 \\
Go to Centro Espiritista & 26.0 \\
Clean house & 26.0 \\
Special necklace & 24.0 \\
Incense & 24.0 \\
Oils & 22.0 \\
Herbs & 18.0 \\
Special masses & 18.0 \\
Consulted spiritualist & 16.0 \\
Tarot cards read & 14.0 \\
Special baths & 12.0
\end{tabular}

Note: All practices done outside of traditional religious contexts. Categories are not mutually exclusive. 
= 10; e.g. "feel more alive," "help for my sickness, more strength and health and get around"); a cure for their illness $(n=9)$; improvement in state of health $(n=6$; e.g. "to feel good and so what I feel can go away," "better health"); three sought relief from pain, two a delay in the onset of their symptoms, and two wanted to "clear their blood" or "get rid of the virus."

Examination of open-ended responses revealed that many participants truly believed that their actions could result in physical improvement. For example, one woman described using a "... cloth that can maintain absorbency for ointment ... [I] say a few things before, healing psalms that reflect healing power of God, [then] cleanse myself with it afterward. My T-cells are going up." Another man described how he was "dead for twenty-one days in a coma and my boyfriend revived me with a pigeon. He cleaned me with the pigeon's blood all over my body."

Two-fifths of practitioners of folk healing said they were seeking spiritual (or emotional) relief, including finding peace, enlightenment, salvation, or absolution. For example, one respondent took special baths of flowers once a month or more often if he was depressed; the baths 'take the depression away, give [me] better understanding and luck'. Others used candles, incense, special herbs or lotions, or other remedies to enhance their spiritual or psychological well-being.

About a quarter of believers said they hoped to ward off evil through their practices. The most common means of doing this was to leave glasses of water out to "take evil spirits out of the environment"; the water is thought to absorb the evil spirits, and is then thrown out the window. Other ways of warding off evil spirits include cleaning the house with ammonia, which is thought to "remove bad influences," and result in a "more purified house and evil spirits get out." Special oils or lotions and incense were also used to keep evil spirits away.

Less commonly, respondents were hoping that folk healing would help them make a life change (e.g. stay off drugs, change their situation), promote general well-being (e.g. get through the day), prolong life (e.g. live more years, wait for a cure) or get advice (given as the reason for tarot card readings).

\section{Predictors of folk healing}

Possible predictors of involvement in folk healing practices were examined by comparing respondents who engaged in espiritismo or santeria $(n=50)$ to those who did not $(n=26)$ on a set of demographic and life circumstance measures. Variables that were not significant predictors of involvement in folk healing were age, sex, educational level, language of the interview, being in some form of therapy, number of family members living nearby, time since diagnosis and de-

Table 3. Reasons for engaging in folk healing (among those reporting any involvement; $n=50$ )

\begin{tabular}{lc}
\hline Reason & $\%$ \\
\hline Physical relief & 44.0 \\
Spiritual relief & 40.0 \\
Ward off evil & 26.0 \\
Life change & 12.0 \\
Well-being & 10.0 \\
Prolong life & 8.0 \\
Obtain advice & 6.0
\end{tabular}

Note: Categories are not mutually exclusive. 
pression. Illness stage emerged as a significant predictor of involvement in folk healing: $87 \%$ of the 23 respondents who were symptomatic engaged in folk healing, compared to $57 \%$ of the 53 asymptomatic respondents (chi-square $=5.3, d f=1, p<0.03$ ). Individuals who engaged in folk healing were more likely to report also engaging in traditional religion $(60 \%$, vs $3.8 \%$ of those not engaged in folk healing; chi-square $=20.1, d f=1, p<0.0001$ ). In addition, among respondents of Puerto Rican origin or descent $(n=68)$, there was an association $(p<0.07)$ between involvement in folk healing and birthplace. More of the respondents born in Puerto Rico reported spiritualist involvement $(35 / 46 ; 76.1 \%)$ than those born in the US $(11 / 22 ; 50 \%)$.

Among the subset of respondents engaging in folk healing, degree of involvement was assessed by counting the number of practices engaged in. Degree of involvement was correlated with the number of family members living nearby $(r=0.31, p<0.02)$ and to the language in which the interview was conducted, with English-speakers reporting a higher number of practices than Spanish-speakers $(\mathrm{M}=5.9$ vs 3.0, $t$-value $=2.3, p<0.03)$. Further analyses revealed that English-speaking respondents had a higher number of family members living nearby (an average of 5.5, vs 2.9 among Spanish-speakers), which might account for this difference, since in many cases family members were engaging in folk healing on behalf of the respondent. Again, degree of involvement was related to diagnosis; the mean number of practices involved in was 6.15 for symptomatic respondents, compared to 3.93 for asymptomatic respondents; $t(38)=1.76, p<$ 0.09). Degree of involvement in folk healing was not related to demographic variables (age, sex, birthplace, level of education) or other variables such as level of depression, time since diagnosis, or being in therapy.

\section{Discussion}

In most societies, individuals have access to multiple health care alternatives, including traditional or folk medicine (Stoner, 1986; Wilkinson \& Sussman, 1987). Folk medical systems are a well-developed and culturally ingrained way of treating both physical (Pachter et al., 1992; Rivera, 1988; Trotter, 1991) and psychological (Hohmann et al., 1990; Schwartz, 1985; Weiss, 1992) illness. The sensitive delivery of health care requires that providers be aware of these beliefs and practices among particular patient populations (Pachter, 1994).

Many of the HIV-positive Hispanics in our study exhibited an active belief in the influence of the spirit world on their physical and emotional well-being, and nearly two-thirds reported engaging in folk healing to manage their illness. Perhaps not surprisingly, involvement in folk medicine was greater among individuals who were further in disease progression, suggesting that in the absence of effective biomedical treatment, individuals fall back on culturally appropriate alternatives to manage and alleviate disease symptoms. The high prevalence of folk beliefs and practices identified among Hispanics seeking biomedical care in an urban area of the eastern US suggests the possibility of a widespread phenomenon of great relevance to HIV/AIDS prevention and treatment efforts. It is unknown how many other affected individuals fail to seek biomedical care and rely solely on folk medical practices to treat their HIV-related conditions. Outreach and education would need to be offered to such people in order to engage them in standard medical care.

This study supports the conclusion that folk healing is a significant coping mechanism for many HIV-positive Hispanics living in the US. A growing body of research suggests that achieving a sense of control is a key to dealing with the uncertainty of HIV illness (McCain \& Gramling, 1992; Solano et al., 1992; Wolf et al., 1991). The present study shows that engaging in folk healing may result in a heightened sense of control over HIV disease. One man described a nightly ritual, when "... my aunt wipes prayer oil on my feet and says a special prayer while I visualize 
destroying all the evil in my body and repairing my immune system." Another stated, "I'm not letting this thing get me without a fight. I'm going to keep on trying different things until I find out what works for me. The doctor says no, I say yes." Active coping styles have been shown to be beneficial not only psychologically but also physically; at least one study has demonstrated an association between active coping style and immune measures (Goodkin et al., 1992). The possibility that engaging in folk healing may have physical benefits is worthy of further investigation.

Few significant associations emerged between involvement in folk healing and demographic or life circumstance variables. This may be due to the small sample size or to the global way in which folk healing involvement was assessed in this exploratory study. Other studies have also found that demographic variables do not predict use of folk healers (Hohmann et al., 1990; Koss, 1987): future research should take into account frequency of folk healing activities and strength of belief in their efficacy, and should assess the relative role of the patient and others in the social network.

This study represents an initial attempt to document beliefs and practices related to folk medicine and spiritualism among HIV-infected Hispanics. It is important to note that Hispanics are not a homogenous group, and that folk beliefs and practices may be expressed differently across Hispanic sub-cultures (Marin \& Marin, 1991). Additionally, not all Hispanics practise folk healing. Thus the findings of this study may not be generalizable to other geographic areas or Hispanic subpopulations. However, the study points to a great need for additional research in this area. It is not known, for example, which folk medical beliefs may be inconsistent with biomedical aetiologies or treatments, and thus how folk beliefs may influence adherence to biomedical regimens. It is also possible that folk beliefs may affect transmission-relevant behaviours such as condom use or needle sharing. Until such research is conducted, health care professionals treating HIV-infected Hispanics should be sensitive to the prevalence of alternative healing practices which may be used by many of their patients and attempt to integrate their medical treatments into a culturally appropriate model.

\section{Acknowledgements}

Funding for this research was provided by the Rutgers University Research Council. The authors wish to thank Peter Guarnaccia for his guidance during the early stages of this research, and Jennifer Pranke for assistance in manuscript preparation.

\section{Address for correspondence:}

Ann O'Leary, Rutgers University, Department of Psychology, Busch Campus, New Brunswick, NJ 08903, USA. Tel. + 1 (908) 445 3174; Fax. + 1 (908) 445 2263. [Dr. O'Leary is currently (2007) with the Centers for Disease Control in Atlanta, Georgia.]

\section{REFERENCES}

CENTERS FOR DISEASE CONTROL AND PREVENTION (1995). HIV/AIDS Surveillance Report, $7(1)$.

GAFNER, G. \& DUCKETT, S. (1992). Treating the sequelae of a curse in elderly Mexican-Americans. Clinical Gerontologist, 11, 145-153.

GARRISON, V. (1977). Doctor, espiritista or psychiatrist? Health-seeking behavior in a Puerto Rican neighborhood of New York City. Medical Anthropology, 1, 65-191.

GONZALEZ-WHIPPLER, M. (1982). The santeria experience. New Jersey: Prentice Hall.

GOODKIN, K., BLANEY, N.T., FEASTER, D., FLETCHER, M.A., BAUM, M.K., MANTERO-ATIENZA, E., KLIMAS, N.G., MILLON, C., SZAPOCZNIK, J. \& EISDORFER, C. (1992). Active coping 
style is associated with natural killer cell cytoxicity in asymptomatic HIV-1 seropositive homosexual men. Journal of Psychosomatic Research, 36, 635-650.

GUARNACCIA, P.J., ANGEL, R. \& WOROBEY, J.L. (1989). The factor structure of the CES-D in the Hispanic health and nutrition examination survey: the influences of ethnicity gender and language. Social Science and Medicine, 29, 85-94.

HOHMANN, A.A., RICHEPORT, M., MARRIOTT, B.M., CANINO, G.J., RUBIO-STIPEC, M. \& BIRD, H. (1990). Spiritualism in Puerto Rico: results of an island-wide community study. British Journal of Psychiatry, 156, 328-335.

KOSS, J.D. (1987). Expectations and outcomes for patients given mental health care or spiritualist healing in Puerto Rico. American Journal of Psychiatry, 144, 56-61.

LUBCHANSKY, I., EGRI, G. \& STOKES, J. (1970). Puerto Rican spiritualists view mental illness: the faith healer as a paraprofessional. American Journal of Psychiatry, 127, 312-321.

MARIN, G. \& MARIN, B.V. (1991). Research with Hispanic Populations. Newbury Park, CA: Sage.

McCAIN, N.L. \& GRAMLING, L.F. (1992). Living with dying: coping with HIV disease. Issues in Mental Health Nursing, 13, 271-284.

NESS, R.C. \& WINTROB, R.M. (1981). Folk healing: a description and synthesis. American Journal of Psychiatry, 138, 1477-1481.

PACHTER, L.M., BERNSTEIN, B. \& OSARIO, A. (1992). Clinical implications of a folk illness: empacho in mainland Puerto Ricans. Medical Anthropology, 13, 285-299.

PACHTER, L.M. (1994). Culture and clinical care: folk illness beliefs and behaviors and their implications for health care delivery. Journal of the American Medical Association, 271, 690-694.

RADLOFF, L.S. (1977). The CES-D scale: a self-report depression scale for research in the general population. Applied Psychological Measurement, 1, 385-401.

RIVERA, G. (1988). Hispanic folk medicine utilization in urban Colorado (curanderismo). Sociology and Social Research, 72, 237-241.

ROGLER, L.L. \& HOLLINGSHEAD, A.B. (1965). Trapped: families and schizophrenia. New York: John Wiley.

SCHWARTZ, D. (1985). Caribbean folk beliefs and western psychiatry. Journal of Psychosocial Nursing and Mental Health Services, 23, 26-30.

SELIK, R.M., CASTRO, K.G., PAPPAIOANOU, M. \& BUEHLER, J.W. (1989). Birthplace and the risk of AIDS among Hispanics in the U.S. American Journal of Public Health, 79, 836-839.

SOLANO, L, COSTA, M., SALVATI, S., CODA, R., AIUTI, F., MEZZAROMA, I. \& BERTINI, M. (1993). Psychosocial factors and clinical evolution in HIV-1 infection: a longitudinal study. Journal of Psycosomatic Research, 37, 39-51.

STONER, P. (1986). Understanding medical systems: traditional, modern, and syncretic health care alternatives in medically pluralistic societies. Medical Anthropology Quarterly, 17, 44-48.

TROTTER, R.T. (1991). A survey of four illnesses and their relationship to intracultural variation in a Mexican-American community. American Anthropologist, 93, 115-125.

US BUREAU OF THE CENSUS. (1995). Residence population estimates for 1995. Washington, DC: Bureau of the Census.

WEISS, C.I. (1992). Controlling domestic life and mental illness: spiritual and aftercare resources used by Dominican New Yorkers. Culture, Medicine and Psychiatry, 16, 237-371.

WILKINSON, D.Y. \& SUSSMAN, M.B. (1987). Medical pluralism in the twentieth century. Marriage and Family Review, 11, 1-9.

WOLF, T.M., DRALLE, P.W., MORSE, E.V., SIMON, P.M., GAUMER, R.H. \& WILLIAMS, M.H. (1991). A biopsychosocial examination of symptomatic and asymptomatic HIV-infected patients. International Journal of Psychiatric Medicine, 21, 263-279. 